\title{
Physical and chemical properties, elemental and material snow composition in Rostov-on- Don
}

\author{
Yuri A. Fedorov*, Daria F. Solodko, Victoria I. Chepurnaya, Irina V. Dotsenko, \\ Boris V. Talpa, Sergey V. Levchenko, Yuri V. Popov, Leonid Yu. Dmitrik \\ Institute of Earth Sciences, Southern Federal University, 344090 Rostov-on-Don, Zorge str. 40, \\ Russia
}

\begin{abstract}
To study the current distribution of the heavy metals (HM) levels and iron in the atmospheric precipitation in Rostov-on-Don, an expedition was conducted aimed at simultaneous river water and snow sampling in the Don River, the roadside and park areas. The $\mathrm{pH}$ values of the melt-water were characterized by a slightly acidic reaction, and the stale snow in the park had lower values in comparison with the fresh snow. The river water was slightly alkaline, and the concentrations of dissolved migration forms of $\mathrm{Pb}, \mathrm{Cd}, \mathrm{Zn}, \mathrm{Ni}, \mathrm{Cr}, \mathrm{Mn}$, and $\mathrm{Fe}$ did not exceed the MPC. The exception was the $\mathrm{Cu}$ content, which exceeded the MPC by 2.4 times. The contents of the dissolved migration forms of $\mathrm{Pb}, \mathrm{Cd}, \mathrm{Zn}, \mathrm{Cu}, \mathrm{Ni}$, and $\mathrm{Fe}$ in snow exceeded their contents in river waters. The $\mathrm{HM}$ and $\mathrm{Fe}$ percentage in suspended form in river water and different snow states is calculated and the sequence series are constructed. The analysis showed that in melt-water, in comparison with river water, there is a higher percentage of the HM and iron in the solution. That may be due to the slightly acidic reaction of the snow water medium, which, as is known, promotes the $\mathrm{HM}$ and $\mathrm{Fe}$ mobilization from the suspension and their transition to the dissolved state. Using electron microscopy and X-ray phase analysis, the suspension composition in the snow of the park zone was studied, which is mainly represented by aggregates of clay minerals, quartz grains, water silicates, feldspars, and organic matter clumps.
\end{abstract}

\section{Introduction}

The heavy metals (the HM) and iron are a special group of chemical elements, which should be studied with special attention not only to their physical and chemical characteristics, but also to the environment features in which they are located [1]. In the contents not exceeding the MPC (the maximum permissible concentration), they do not pose a threat to the existence of biota. If this threshold value is exceeded, the HM's can have toxic and mutagenic effects on aquatic and terrestrial landscapes components [2]. Atmospheric precipitation is an important source of heavy metals entering the aquatic and

\footnotetext{
*Corresponding author: fedorov@sfedu.ru
} 
terrestrial ecosystems in the Azov Sea basin. The Rostov-on-Don agglomeration is one of them. Despite this, the HM content in atmospheric precipitation is not limited by the values of maximum permissible concentrations (the MPC). As a rule, scientists who study the troposphere pollution of urbanized areas are guided by the HM concentrations in the precipitation of background areas. The first large-scale studies of the HM content in atmospheric precipitation, including mercury, were first presented in $[2,3,4]$. They revealed a high degree of the HM contamination of hydrometeorological equipment in Rostov-onDon and the satellite cities. Since that time, almost 20 years have passed and events have occurred (for example, a decline in industrial production) that could affect the chemical elements levels in atmospheric precipitation.

To study the patterns of the current distribution HM and iron levels in the atmospheric precipitation in Rostov-on-Don, as one of the priority pollution sources in the Don River and other reservoirs and watercourses of the Azov Sea basin, in February 2020, an expedition was conducted. It was aimed at simultaneous river water sampling in the Don River, as well as fresh and stale snow to determine the major ions content, the $\mathrm{HM}(\mathrm{Pb}, \mathrm{Cd}$, $\mathrm{Zn}, \mathrm{Cu}, \mathrm{Ni}, \mathrm{Cr}, \mathrm{Mn}$ ) and $\mathrm{Fe}$ in roadside and park areas [5].

\section{Materials and methods}

Rostov-on-Don is the regional center of the Rostov Region, the capital of the Southern Federal District, located on the right bank of the Don River and the pontic plateau of the Don-Tuzlovsky watershed with absolute elevations of 90-100 $\mathrm{m}$. The hydrographic network is represented by the main waterway of the region - the Don River, small rivers, lakes and artificial reservoirs. The north-eastern edge of the Proletarian district (until 1929 Nakhichevan) is occupied by the territory of the Park of Culture and Recreation named after N. Ostrovsky. The boundaries of the park are: in the north - along the $1^{\text {st }}$ Horse Army street, in the south - the park is bounded by Sholokhov avenue, from the west - by the $14^{\text {th }}$ line, and from the east - by Selmash avenue. The uniqueness of the expedition was the simultaneous precipitation and water sampling in the Don River. During the expedition (12.02.2020), the air temperature reached negative values $\left(-6^{\circ} \mathrm{C}\right)$, the wind speed $-7.4 \mathrm{~m} / \mathrm{s}$ (East direction), the pressure $-762 \mathrm{mmHg}$. The humidity of the air is $88 \%$ [5].

Two river water samples were taken from a depth of 0.0-0.5 $\mathrm{m}$ at the station 1 (near the Embankment of Rostov-on-Don), and snow samples were taken at the Embankment roadside (the station 1.1), Selmash Ave. (the station 2) and at 4 stations in the Ostrovsky Park (Fig. 1a, 1b). Sampling was accompanied by snowfall, which formed a loose layer on the previously fallen (05.02.2020 - 06:00) dense the stale snow. An expedition was conducted, which was aimed at simultaneous river water sampling, as well as fresh and stale snow to determine the $\mathrm{pH}$ values, major ions, heavy metals $(\mathrm{Pb}, \mathrm{Cd}, \mathrm{Zn}, \mathrm{Cu}, \mathrm{Ni}, \mathrm{Cr}$, $\mathrm{Mn}$ ) and iron content. The samples are prepared for measurement (melted at room temperature). They were pre-filtered through a $0.45 \mathrm{~mm}$ diameter filter and then preserved with nitric acid $\left(\mathrm{HNO}_{3}\right)$ to a $\mathrm{pH}$ value $<2$. The determinations were made in both filtered and pre-acidified unfiltered water. The dissolved migration form was determined in filtered water, and the gross content of elements was determined in unfiltered water. The difference between the total elements content and the dissolved form content was used to determine the suspended form of metal migration [6]. The determination of the HM and iron content was carried out by the atomic absorption analysis method with flame and electrothermal atomization according to the method GD 52.24.377-2008 at the Hydrochemical Institute (Roshydromet). The chemical elements content in the dissolved migration form was compared with the MPC [7]. The $\mathrm{pH}$ values were determined in natural water, immediately after its selection. To determine the hydrogen index, licensed $\mathrm{pH}$ devices were used «Ecotest-2000» ionomer meters. 


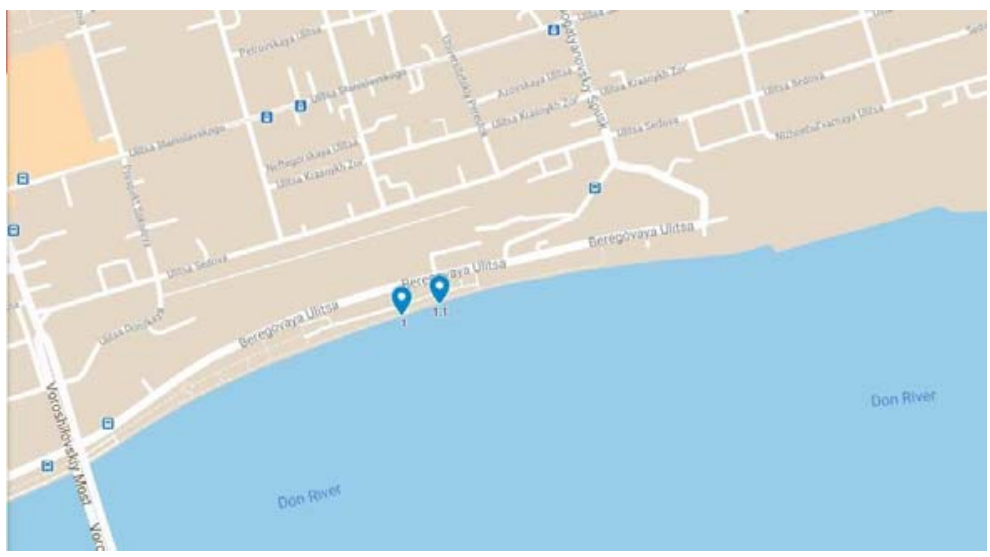

Fig. 1a. Map of the study area (the Embankment area in Rostov-on-Don) (made by the authors according to the data maps.google.ru).

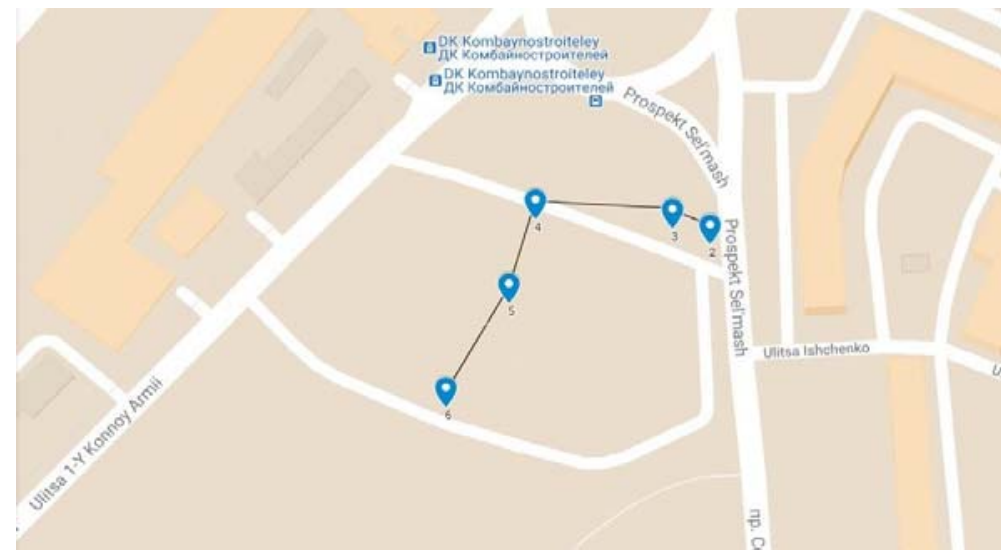

Fig. 1b. Map of the study area (The Ostrovsky Park in Rostov-on-Don) (made by the authors according to the data maps.google.ru)

The sample was represented by dark gray ice with organo-mineral material frozen in it at the station 2. At the stations 3-6, some samples were taken from a freshly fallen and decayed compacted, crystallized snow layer with a grayish hue and inclusions of organic and mineral mass (Fig. 2). The soil under that snow layer was not yet completely frozen, as a result, the transformation of leaf litter continued under the snow cover with the formation of carbon dioxide and related products of biodegradation of buried organic matter. There is a clear border between the newly fallen white loose snow and the stale snow (shown by the arrows) [5]. In total, during the expedition, the participants took samples at 7 stations at the same time. 


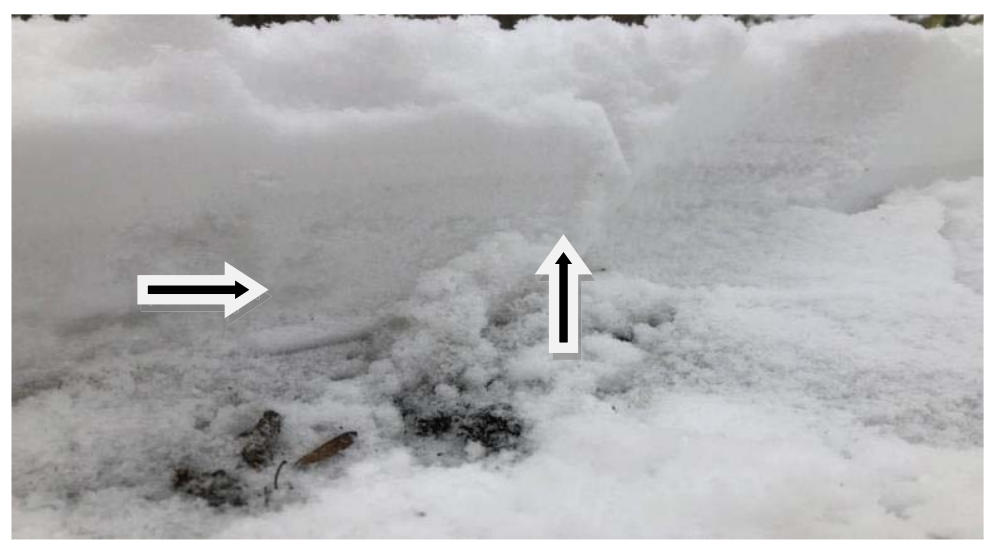

Fig. 2. Snow cover stratification at the station 6

In order to obtain information about the morphology and composition of roadside dust particles, the material remaining on the filter after the melt water filtration was studied. As a result of filtration of water through membrane filters, the selected samples were separated into a liquid and a solid (insoluble in water) phase. The material was studied on white filter paper using a USB MiViewCap digital microscope with a magnification of 10 to 200 times. This made it possible to observe, measure particle sizes, and capture the image. Using the DRON-7 X-ray diffractometer, the X-ray phase analysis of the substance remaining on the filter was performed. The microstructure and elemental composition were studied using a VEGA II LMU scanning electron microscope (manufactured by Tescan) with INCA ENERGY 450/XT energy dispersive microanalysis systems (Silicon Drift detector (ADD)). The images were obtained using a BSE detector.

\section{Results and discussion}

In snow water, $\mathrm{pH}$ values ranged from 5.3 to 7.7 (average 6.3). The reaction of the medium was characterized as weakly acidic. Stale snow in the park had a $\mathrm{pH}$ range of 5.5-6.2 (average 5.7), and freshly fallen snow - 6.3-7.0 (average 6.6). Possibly, the decreased acidity of the melt water obtained from the stale snow in the park is due to the fact that the transformation of deciduous litter continued under the snow cover with the formation of carbon dioxide and related products of biodegradation of buried organic matter. This led to a decrease in the $\mathrm{pH}$ of the melt water in them. The roadside sample contains a lot of soil dust and technogenic substances, which, apparently, contributed to the formation of a weakly alkaline reaction in the melt water. PH values of water in the Don River in its natural state varied in the range 8.0-8.2 (average 8.1), which corresponded to a weak alkaline reaction of the medium. Noteworthy is the increase in $\mathrm{pH}$ values in the direction of melt water $\rightarrow$ river water. In our opinion, this is due to the fact that the $\mathrm{pH}$ value of hydrometeors, especially in winter, is affected by the influence of acid emissions from the combustion of liquid and solid fuels. On the way of transit to the final objects of water flow, the water interacts with the underlying rocks and soils containing carbonates. This contributed to the neutralization of dissolved carbon dioxide and, consequently, to an increase in the $\mathrm{pH}$ values in it. Mineralization of river water in the Don River within the city limits of Rostov-on-Don was $1071 \mathrm{mg} / \mathrm{cm}^{3}$, and thawed water $16.5-21.1 \mathrm{mg} / \mathrm{cm}^{3}$.

In river water, the content of the dissolved form of lead migration varied from 0.4 to 0.5 $\mathrm{mg} / \mathrm{dm}^{3}$ (on average, $0.45 \mathrm{mg} / \mathrm{dm}^{3}$ ), while the cadmium content did not fluctuate and the average value was $0.06 \mathrm{mg} / \mathrm{dm}^{3}$. The content of zinc, copper and nickel was distributed accordingly - from 2.1 to $2.2 \mathrm{mg} / \mathrm{dm}^{3}$ (average $2.15 \mathrm{mg} / \mathrm{dm}^{3}$ ), from 2.0 to $2.7 \mathrm{mg} / \mathrm{dm}^{3}$ 
(average $2.35 \mathrm{mg} / \mathrm{dm}^{3}$ ) and from 0.01 to $0.03 \mathrm{mg} / \mathrm{dm}^{3}$ (on average $0.02 \mathrm{mg} / \mathrm{dm}^{3}$ ). The concentrations of the dissolved form of chromium migration varied from 1.0 to $1.1 \mathrm{mg} / \mathrm{dm}^{3}$ (average value $1.05 \mathrm{mg} / \mathrm{dm}^{3}$ ), manganese - from 10 to $17 \mathrm{mg} / \mathrm{dm}^{3}$ (average $13.5 \mathrm{mg} / \mathrm{dm}^{3}$ ) and iron - from 0.026 to $0.046 \mathrm{mg} / \mathrm{dm}^{3}$ (the average is $0.036 \mathrm{mg} / \mathrm{dm}^{3}$ ).

The content of the dissolved form of migration of $\mathrm{Pb}, \mathrm{Cd}, \mathrm{Zn}, \mathrm{Cu}, \mathrm{Ni}, \mathrm{Cr}, \mathrm{Mn}$, and $\mathrm{Fe}$ in freshly fallen snow varied, respectively, in the range from 0.5 to $1.5 \mathrm{mg} / \mathrm{dm}^{3}$ (on average $1.03 \mathrm{mg} / \mathrm{dm}^{3}$ ), from 0.07 to $0.40 \mathrm{mg} / \mathrm{dm}^{3}$ (average $0.20 \mathrm{mg} / \mathrm{dm}^{3}$ ), from 5.5 to $10.0 \mathrm{mg} / \mathrm{dm}^{3}$ (average $7.5 \mathrm{mg} / \mathrm{dm}^{3}$ ), from 3.4 to $11.0 \mathrm{mg} / \mathrm{dm}^{3}$ (on average $6.7 \mathrm{mg} / \mathrm{dm}^{3}$ ), from 0.01 to 0.50 $\mathrm{mg} / \mathrm{dm}^{3}$ (on average $0.15 \mathrm{mg} / \mathrm{dm}^{3}$ ), from 0.05 to $0.50 \mathrm{mg} / \mathrm{dm}^{3}$ (on average $0.19 \mathrm{mg} / \mathrm{dm}^{3}$ ), from 2.1 to $7.0 \mathrm{mg} / \mathrm{dm}^{3}$ (on average $4.70 \mathrm{mg} / \mathrm{dm}^{3}$ ) and from 0.015 to $0.057 \mathrm{mg} / \mathrm{dm}^{3}$ (on average $0.043 \mathrm{mg} / \mathrm{dm}^{3}$ ).

The content of the dissolved form of lead migration in stale snow varied from 0.6 to 1.1 $\mathrm{mg} / \mathrm{dm}^{3}$ (average $0.8 \mathrm{mg} / \mathrm{dm}^{3}$ ), cadmium from 0.11 to $0.33 \mathrm{mg} / \mathrm{dm}^{3}$ (average $0.24 \mathrm{mg} / \mathrm{dm}^{3}$ ), zinc from 5.2 to $7.1 \mathrm{mg} / \mathrm{dm}^{3}$ (average $6.2 \mathrm{mg} / \mathrm{dm}^{3}$ ), copper from 2.7 to $11.0 \mathrm{mg} / \mathrm{dm}^{3}$ (average $6.1 \mathrm{mg} / \mathrm{dm}^{3}$ ), nickel from 0.06 to $0.50 \mathrm{mg} / \mathrm{dm}^{3}$ (on average $0.34 \mathrm{mg} / \mathrm{dm}^{3}$ ), chromium from 0.05 to $0.70 \mathrm{mg} / \mathrm{dm}^{3}$ (on average $0.30 \mathrm{mg} / \mathrm{dm}^{3}$ ), manganese from 3.3 to 6.7 $\mathrm{mg} / \mathrm{dm}^{3}$ (on average $4.8 \mathrm{mg} / \mathrm{dm}^{3}$ ) and iron from 0.027 to $0.088 \mathrm{mg} / \mathrm{dm}^{3}$ (on average 0.059 $\mathrm{mg} / \mathrm{dm}^{3}$ ). In ice samples with road dust frozen into it, it was found that the content of the dissolved form of lead migration was $0.8 \mathrm{mg} / \mathrm{dm}^{3}$, cadmium $-0.4 \mathrm{mg} / \mathrm{dm}^{3}$, zinc -3.0 $\mathrm{mg} / \mathrm{dm}^{3}$, copper $-8.7 \mathrm{mg} / \mathrm{dm}^{3}$, nickel $-1.0 \mathrm{mg} / \mathrm{dm}^{3}$, chromium $-1.0 \mathrm{mg} / \mathrm{dm}^{3}$, manganese $3.6 \mathrm{mg} / \mathrm{dm}^{3}$, iron $-0.1 \mathrm{mg} / \mathrm{dm}^{3}$. Comparison of the retrospective contents of $\mathrm{HM}$ and iron in the dissolved form of migration, presented in [3,7] with the modern ones, showed a tendency towards a decrease in their levels to date.

The content of lead in suspension of river water varies from 0.3 to $0.4 \mathrm{mg} / \mathrm{dm}^{3}$ (on average $-0.35 \mathrm{mg} / \mathrm{dm}^{3}$ ), cadmium - from 0.09 to $0.11 \mathrm{mg} / \mathrm{dm}^{3}$ (on average $0.1 \mathrm{mg} / \mathrm{dm}^{3}$ ), zinc - from 3.3 to $3.5 \mathrm{mg} / \mathrm{dm}^{3}$ (average $3.4 \mathrm{mg} / \mathrm{dm}^{3}$ ), copper - from 0.7 to $1.1 \mathrm{mg} / \mathrm{dm}^{3}$ (average $0.9 \mathrm{mg} / \mathrm{dm}^{3}$ ). For nickel, the average concentration is $0.04 \mathrm{mg} / \mathrm{dm}^{3}$, for chromium, concentrations vary from 15.0 to $16.0 \mathrm{mg} / \mathrm{dm}^{3}$ (on average, $15.5 \mathrm{mg} / \mathrm{dm}^{3}$ ). The concentration of iron in suspended matter varies from 0.064 to $0.066 \mathrm{mg} / \mathrm{dm}^{3}$ (on average $0.065 \mathrm{mg} / \mathrm{dm}^{3}$ ). In river water, on average, a tendency towards predominant accumulation of $\mathrm{Cd}, \mathrm{Zn}, \mathrm{Ni}, \mathrm{Mn}$, and $\mathrm{Fe}$ in suspended matter was observed, and $\mathrm{Pb}, \mathrm{Cu}$, and $\mathrm{Cr}-$ in the dissolved form of migration. As a percentage, the accumulative series of elements (the ratio of the content of metals in suspension to their total content) takes the following form $-\mathbf{N i}>$ $\mathrm{Fe}>\mathrm{Cd}>\mathrm{Zn}>\mathrm{Mn}>\mathrm{Pb}>\mathrm{Cu}>\mathrm{Cr}$.

The lead content in freshly fallen snow varied in the range from 0.8 to $2.3 \mathrm{mg} / \mathrm{dm}^{3}$ (on average $1.5 \mathrm{mg} / \mathrm{dm}^{3}$ ), cadmium - from 0.06 to $0.32 \mathrm{mg} / \mathrm{dm}^{3}$ (on average $0.18 \mathrm{mg} / \mathrm{dm}^{3}$ ), zinc - from 1.2 to $6.0 \mathrm{mg} / \mathrm{dm}^{3}$ (average $3.85 \mathrm{mg} / \mathrm{dm}^{3}$ ), copper - from 2 to $8 \mathrm{mg} / \mathrm{dm}^{3}$ (average $4.85 \mathrm{mg} / \mathrm{dm}^{3}$ ), nickel - from 0.03 to $1.50 \mathrm{mg} / \mathrm{dm}^{3}$ (on average $0.54 \mathrm{mg} / \mathrm{dm}^{3}$ ), chromium from 0.60 to $1.05 \mathrm{mg} / \mathrm{dm}^{3}$ (on average $0.80 \mathrm{mg} / \mathrm{dm}^{3}$ ), manganese - from 3.7 to $8.1 \mathrm{mg} / \mathrm{dm}^{3}$ (on average $5.6 \mathrm{mg} / \mathrm{dm}^{3}$ ). The concentration of iron in suspended matter varied from 0.069 to $0.293 \mathrm{mg} / \mathrm{dm}^{3}$ (on average, $0.190 \mathrm{mg} / \mathrm{dm}^{3}$ ). Concentrations of lead in stale snow varied from 0.9 to $2.1 \mathrm{mg} / \mathrm{dm}^{3}$ (on average $1.4 \mathrm{mg} / \mathrm{dm}^{3}$ ), cadmium - from 0.07 to $0.27 \mathrm{mg} / \mathrm{dm}^{3}$ (on average $0.20 \mathrm{mg} / \mathrm{dm}^{3}$ ), zinc - from 2.2 to $43.0 \mathrm{mg} / \mathrm{dm}^{3}$ (average $14.8 \mathrm{mg} / \mathrm{dm}^{3}$ ), copper from 1.3 to $33.3 \mathrm{mg} / \mathrm{dm}^{3}$ (average $10.7 \mathrm{mg} / \mathrm{dm}^{3}$ ), nickel - from 0.13 to $4.0 \mathrm{mg} / \mathrm{dm}^{3}$ (average $1.80 \mathrm{mg} / \mathrm{dm}^{3}$ ), chromium - from 0.4 to $5.8 \mathrm{mg} / \mathrm{dm}^{3}$ (average $1.9 \mathrm{mg} / \mathrm{dm}^{3}$ ) and manganese from 3.0 to $16.2 \mathrm{mg} / \mathrm{dm}^{3}$ (average $9.1 \mathrm{mg} / \mathrm{dm}^{3}$ ). The concentration of iron in suspended matter varied from 0.052 to $0.97 \mathrm{mg} / \mathrm{dm}^{3}$ (on average $0.30 \mathrm{mg} / \mathrm{dm}^{3}$ ). There were no significant differences in the HM and Fe contents in freshly fallen and lying snow. The percentage of $\mathrm{HM}$ in suspended form in snow of various states corresponds to the following gradation: $\mathbf{C r}>\mathbf{F e}>\mathbf{N i}>\mathbf{P b}>\mathbf{M n}>\mathbf{C u}>\mathbf{Z n}>\mathbf{C d}$. The analysis showed that in melt water, in comparison with river water, there is a higher percentage of $\mathrm{HM}$ and $\mathrm{Fe}$ in the solution. 
This may be due to the acidic reaction of the snow water. As is known [8], even a slight acidification of the aqueous medium promotes the mobilization of HMs and Fe from suspended matter and their transition to a dissolved state.

Since the essential role of suspended matter in the accumulation of HM is shown above in the text, it was important to know how it is represented. Microparticles in the dust fraction of snow samples are represented by soil particles, aggregates of clay particles (mainly chlorite-illite composition), fine sandy-silty grains of quartz $(\sim 80 \%$ of the terrigenous fraction), calcite, feldspars, gypsum, single grains of magnetite and titanomagnetite. Technogenic objects in the roadside sample were represented by aluminosilicate microspheres, metal particles of varying degrees of corrosion (steel, brass, products of destruction of galvanized metal coatings, aluminum alloys, etc.), carbon (soot) particles (Fig. 3). As we moved deeper into the park zone, a relative decrease in the content of terrigenous grains and an increase in the amount of soil and clay particles were observed.

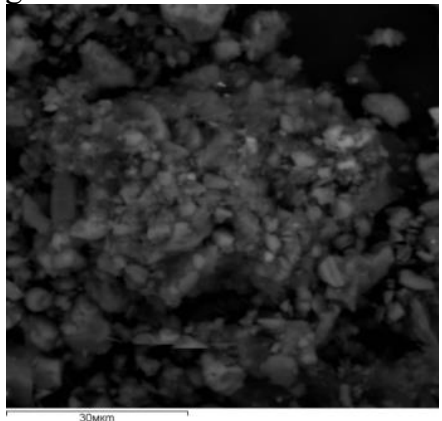

a

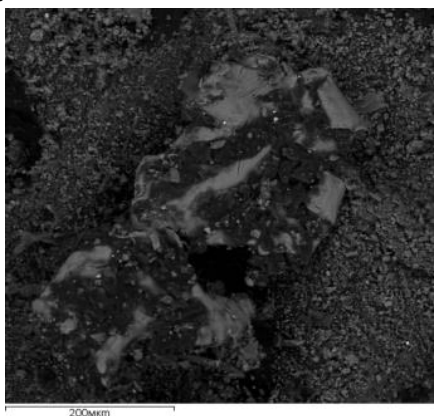

$\mathrm{c}$

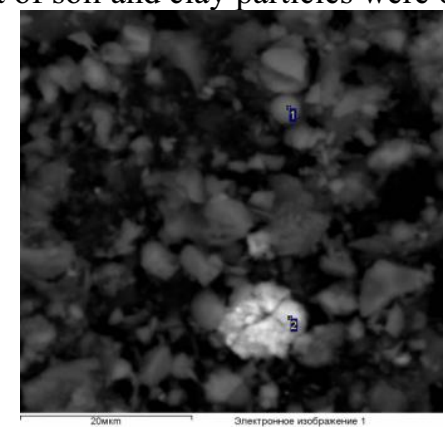

b

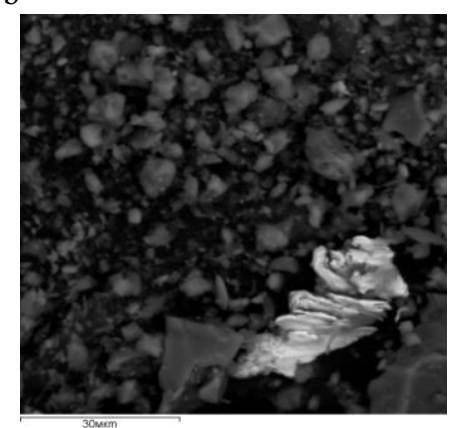

$\mathrm{d}$

Fig.3. Typical microparticles in the composition of snow samples: a - soil clay aggregate (organic soil components, silicate minerals and calcite); b - particles of technogenic origin: in Fig. b: 1 aluminosilicate microsphere, 2 - fragment of $\mathrm{Cu}-\mathrm{Zn}$ composition, $\mathrm{c}$ - aluminum foil, $\mathrm{d}$ - steel particle). Station 2. Image of the BSE.

\section{Conclusions}

A complex expedition was carried out, the purpose of which was a one-time sampling of river water in the Don River and snow in the roadside and park area of Rostov-on-Don. They determined the values of $\mathrm{pH}$, mineralization, the content of $\mathrm{HM}(\mathrm{Pb}, \mathrm{Cd}, \mathrm{Zn}, \mathrm{Cu}, \mathrm{Ni}$, $\mathrm{Cr}, \mathrm{Mn}$ ) and $\mathrm{Fe} . \mathrm{pH}$ of water in the Don River in its natural state varied in the range 8.0-8.2 (average 8.1), which corresponded to a weak alkaline reaction of the medium, while melt water was characterized by lower values. In this way it's founded the increase in $\mathrm{pH}$ values in the direction of melt water $\rightarrow$ river. The river water was slightly alkaline, and the concentration of dissolved forms of migration of $\mathrm{Pb}, \mathrm{Cd}, \mathrm{Zn}, \mathrm{Ni}, \mathrm{Cr}, \mathrm{Mn}$, and $\mathrm{Fe}$ in it did 
not exceed the MPC. Only the Cu content exceeded the MPC by 2.4 times. The contents of the dissolved form of migration of $\mathrm{Pb}, \mathrm{Cd}, \mathrm{Zn}, \mathrm{Cu}, \mathrm{Ni}$, and $\mathrm{Fe}$ in the snow were higher than their contents in river waters. The content of $\mathrm{Cr}$ and, to a greater extent, $\mathrm{Mn}$, on the contrary, were higher in river waters in comparison with hydrometeors. Comparison of retrospective $\mathrm{HM}$ and $\mathrm{Fe}$ concentrations in atmospheric precipitation with modern ones showed a decrease in their concentration levels over time. The analysis showed that in melt water, compared to river water, there is a higher percentage of HM and iron in dissolved form. This may be due to the weakly acidic reaction of the snow water environment, which, as is known, promotes the mobilization of $\mathrm{HM}$ and $\mathrm{Fe}$ from the suspension and their transition into a dissolved state. Using electron microscopy and X-ray phase analysis, the material composition of suspension in the snow of the park and roadside zones, which is mainly represented by aggregates of clay minerals, grains of quartz, hydrous silicates, feldspars, and clots of organic matter, has been studied. In the crystallized snow with frozen roadside dust, the presence of technogenic objects received as a result of burning was also established.

Instrumental studies of the material composition of snow serve as evidence of the influence of technogenic formations on the increased content of $\mathrm{HM}$ and $\mathrm{Fe}$ in melt water. Atmospheric precipitation in urbanized areas, despite the outlined decrease in the concentration of $\mathrm{Pb}, \mathrm{Cd}, \mathrm{Zn}, \mathrm{Cu}, \mathrm{Ni}, \mathrm{Cr}, \mathrm{Mn}$, and $\mathrm{Fe}$, remains one of the priority sources of surface water pollution in the Azov Sea basin.

The work was carried out with the financial support of the RFBR, projects No. 19-05-00770 (determination of iron content, development of research methods) and No. 19-05-50097 (conducting an expedition, summarizing, and analyzing the results).

\section{References}

1. Yu.A. Fedorov, I.V. Dotsenko, A.V. Mikhailenko, Izvest. vys. ucheb. zaved. Estestv. Nauki, 3, 108-112 (2015) (in Russian)

2. Yu.A. Fedorov, A.V. Mikhailenko, L.Y. Dmitrik, I.V. Dotsenko, D.F. Solodko, V.Ichepurnaya, Limn. and Freshw.Bio., 4, 838-839 (2020)

3. A. A. Klenkin, I. G. Korpakova, L. F. Pavlenko, Z. A. Temerdashev, Ecosystem of the Azov Sea: the anthropogenic pollution (Enlightenment-South, Krasnodar, 2007)

4. RD 52.24.377-2008., (2008) (in Russian)

5. J.W. Moore, S. Ramamoorthy, Heavy Metals in Natural Waters (1987)

6. Ministry of agriculture of the Russian Federation, Order № 552 dated December 13, 2016 (in Russian)

7. D.F. Solodko, V.I. Chepurnaya, Yu.A. Fedorov, D.N. Garkusha, B.V. Talpa, A.V. Mikhailenko, Ecological Problems. A Look into the Future. Proceedings of the IX International Scientific and Practical Conference, 585-590 (2020) (in Russian)

8. V.V. Privalenko, O.S. Bezuglova. Ekologicheskie problemy antropogennyh landshaftov Rostovskoj oblasti, Volume 1: Environment of Rostov-on-Don, (2003) (in Russian) 